\title{
Governance Agenda for Sub-Saharan Africa Issues and Challenges
}

\author{
Andrew M Kerandi, Carleton University \\ School of Public Policy and Administration, PhD Candidate
}

Poor governance is increasingly being cited as one of the most important factors contributing to poor economic performance in most developing countries. The World Bank has repeatedly argued that poor economic performance in most developing countries, particularly in SubSaharan Africa (SSA), is attributed to poor governance. The issue of governance was first raised in 1988 in the World Bank report evaluating ten years of structural adjustment lending experience. The report noted that "severe institutional and managerial weaknesses in the public and private sector have proved unexpectedly serious as constraints to better performance" (World Bank, 1988: 3). The issue of "good governance" was further amplified by the 1989 World Bank report on SSA when the crisis in the region was termed as a "crisis of governance" (World Bank, 1989). International financial institutions (IFIs) have since then focused on improving the effectiveness of public sector institutions and the performance of public policies. As observed by Naim (1999), the rediscovery of institution has become the key focus of IFIs in as far as reforms are concerned. Naim explains that "no speech or policy paper could be written about market reform without including a fashionable reference to the need to strengthen institutions" (Naim, 1999:12).

IFIs have repeatedly justified their involvement in promoting governance in developing countries arguing that it falls directly within their mandate and expertise (IMF, 2003). The IMF states that it "places great emphasis on good governance when providing policy advice, financial support, and technical assistance to its 184 member countries" (IMF, 2002). On its part, the World Bank says that its fundamental role is to help countries work better and it cannot afford to turn away when "a country is plagued by deeply dysfunctional public institutions that limit accountability, set perverse rules of the game, and are incapable of sustaining development” (World Bank, 2004).

Since the 1990s both multilateral and bilateral donors have factored governance agendas into their financial assistance to developing countries. Many governance projects or initiatives have emerged over the years with the aim to promote democracy, reduce corruption, increase 
transparency, and expand human capabilities (World Bank, 1997). For instance, Santiso (2002) notes that since 1996 World Bank has been actively involved in over 600 governance-related programs in 95 countries and is involved in supporting significant programs of governance and public sector reform in 50 countries. Other donors are also doing the same and thus leading to increased focus in governance agendas for most countries in the SSA region (Grindle, 2004).

The increasing importance of governance agenda raises several questions that require further study and analysis. What are the key issues that will affect the success of these governance initiatives? Will these initiatives succeed in ultimately eradicating poverty in most of these developing countries and improving their economic performance? Should governance agendas be a top priority for countries in the SSA region? Although the intent and objectives of these governance initiatives is highly desirable, they are inherently unrealistic and their implementation faces serious challenge for the governments. These challenges include reducing poverty levels (which have shown a persistent increase over the years and directly undermine good governance initiatives); institutionalizing the rule of law; and arresting the spread of HIV/AIDS (which currently poses serious threats to good governance). These challenges are closely interrelated and clearly will determine the success of these governance initiatives. This paper argues that, instead of emphasizing the governance agendas (which are inherently slow and long term in nature), efforts should be more focused on minimizing the impact of the challenges mentioned above (i.e., poverty, legal reform, and HIV/AIDS). This paper will discuss these challenges and briefly highlight how they will impact on good governance. But before I discuss each of these challenges, I will highlight (i) the complexities involved in defining the term "good governance”, and (ii) the unrealism embedded in the governance agenda.

\section{I: The Meaning of Good Governance}

The terms “governance” or "good governance” have no universal meaning. Ahrens (2001) observes that "there is no clear or settled ideas about how effective governance should be suitably defined, let alone how key governance related issues can be appropriately incorporated into externally-financed programmes of policy reform” (Ahrens [2001:54] as cited in Santiso, 2002). In spite of the lack of an agreed usage of the term "governance", many multinational and bilateral donors and other development practitioners have attempted to provide working definitions for the term. The World Bank defined governance as "the institutional capability of 
public organizations to provide the public and other goods demanded by a country's citizens or their representatives in an effective, transparent, impartial, and accountable manner” (World Bank, 2000:48). To this end, the World Bank views good governance as demonstration of "predictable, open and enlightened policy making (that is, transparent process); a bureaucracy imbued with a professional ethos; an executive arm of government accountable for its actions; and a strong civil society participating in public affairs; and all behaving under the rule of law” (Thomas, 2004:4).

The IMF defines governance as "all aspects of the way a country is governed, including its economic policies and regulatory framework” which includes ensuring the rule of law, improving the efficiency and accountability of the public sector, and tackling corruption (IMF, 2003).

Panday (2004) argues that governance should be viewed from both domestic and international perspectives. He further contends that "any country that is dependent on aid for development has to account to the donors for its state of governance and do what is necessary for improvement, both as an end and a means of development” (Panday, 2004:42). Toward this end, the African Development Bank (AfDB), the first regional multilateral development bank to adopt an official strategy on governance, defines governance within a global context. AfDB's report on governance argues that governments should "find a balance between taking advantage of globalization and providing a secure and stable social and economic domestic environment” (AfDB, 2000:3). Thus, AfDB defines governance as "a process referring to the manner in which power is exercised in the management of the affairs of a nation, and its relations with other nations”. This is particularly appropriate in view of the fact that tackling some of the problems related with governance requires actions at the global level.

There are also divergent views on what constitutes good governance. AfDB views good governance as “sound development management” based on five interrelated pillars: accountability, transparency, combating corruption, participation and an enabling legal/judicial framework (AfDB, 2004). In addition, World Bank’s researchers, Kaufmann and Kraay (1999) express similar views and have identified the main dimensions of good governance as: voice and accountability (which includes civil liberties); political stability and absence of violence; government effectiveness (which includes the quality of policy making and public service 
delivery); regulatory quality; rule of law (which includes protection of property rights and independence of the judiciary); and control of corruption.

Governance can be broad and have different means and approaches towards its attainment. But there seems to be a general consensus that good governance is a major ingredient to economic development. The Organization for Economic Cooperation and Development (OECD) argues that good, effective public governance helps to strengthen democracy and human rights, promote economic prosperity and social cohesion, reduce poverty, enhance environmental protection, ensure the sustainable use of natural resources and deepen the confidence in government and public administration (OECD, 2005). Furthermore, Kaufman et al (1999) described governance as "tradition and institutions by which authority in a country is exercised for the common good”. Nyong’o (2001) expresses similar views, arguing that good governance should be assessed based on how effective governments perform their work and promote public good.

In short, good governance is considered to lead to sustainable development. Keefer and Knack (1995)'s study on the role of institutions on economic development found that good governance, in the form of institutions that establish a predictable, impartial, and consistently

enforced set of rules for investors, is crucial for the sustained per capita income growth of poor countries. It is for this reason that multilateral donors such as the World Bank and IMF have been actively involved in governance initiatives in most developing nations including those from the SSA region. The main focus of IFIs has thus been in assisting African governments to create, protect, and enforce property rights; to provide a sound macroeconomic regime; and to create institutions that limit state capacity for arbitrary action in order to improve its ability to support broad-based markets (World Bank, 2002:99-101).

\section{II: Unrealism in Governance Agendas}

The governance agendas seem to be unrealistic and difficult to implement. There are two factors that make most of the governance initiatives unrealistic. First, the governance agendas have assumed that most of the governance problems confronting developing countries can be tackled through a technical approach. And secondly, governance agendas pursued in most SSA countries are too broad and ambitious to realize any meaningful benefits. I will now discuss further these two factors. 


\section{Inappropriate Technical Approach}

The implementation of most governance initiatives has embraced a functionalist or technical approach. The basic assumption being employed in tackling governance problems in most developing countries is that “technical solutions can solve political problems” (Santiso:2002:13). This approach embraces the rational model of decisionmaking that assumes that policy is created in a fairly orderly sequence of stages. The approach views policy as an outcome of a sphere of rational analysis, while it considers politics as a sphere of irrationality. While this simplistic reasoning has worked in some countries, it has and will most likely not deliver any meaningful results in most countries. For instance, most multilateral donors, especially the WB and IMF, firmly believe that holding multi-party elections is usually taken as a proof of the existence of good democratic governance. Although this is possible in some contexts, it does not deliver fair representation in most African countries where party affiliation tends to follow tribal lines. Nyong'o argues,

elections, by themselves, are not enough. A democratic political culture involves deeper participation at local levels, less concentration of political power at the center, institutionalization of the rule of law and respect for human rights, including social rights. (Nyong'o, 2002:6)

Governance initiatives like this that extricate policy from the realities of the political landscape in these countries are far fetched and will most certainly fail to deliver the expected results. Governance agendas must take into consideration the political realities existing in most of these developing nations. IFIs seem to place more emphasis on economic dimensions of governance and ignore the political dimensions (IMF [1997] as cited in Santiso [2002]). Jayasuriya and Hewison (2004: 571) also found that most governance projects aim to shape and discipline social conduct within the civil society and mainly serve "to promote consensus over economic and social reform through mechanisms that enable the technocratic management of social conflict”. The focus of these projects is on "government effectiveness" ignoring the "legitimacy of government". Legitimacy of the government refers to accepting the government as "correct, appropriate and or right” (Brinkerhoff, 2005:5). The issue of legitimacy of the government is another challenge confronting governance agenda in most developing countries as discussed under section III.2. 


\section{Too Broad and Ambitious}

Most governance agendas are too broad and inherently ambitious, posing insurmountable implementation challenges as a result. A review of African PRSPs by UNCTAD revealed that most countries have many governance-related reforms all pursued simultaneously. As per the UNCTAD report, governance agendas included:

[A]nti-corruption measures; improved, more participatory and accountable public administration; transparency in the preparation and monitoring of budgetary expenditures; legal reforms aiming at securing property rights and strengthening institutions that affect private sector activity; reforming procurement systems: rule of law; human rights; or briefly the "architecture of the state”. (UNCTAD, 2002:51)

UNCTAD argues that the "implementation of such an all-encompassing and ambitious agenda, pursued through loan and debt-relief conditionalities would require far-reaching changes in African systems of government, including major constitutional changes” (UNCTAD, 2002:51). These broad-based ambitious governance agendas have over-stretched most developing countries, in terms of time and resources. Grindle (2004) expresses similar views pointing out that governance agendas pose serious difficulties as guides to development. Grindle (2004) argues that

getting good governance calls for improvements that touch virtually all aspects of the public sector - from institutions that set the rules of the game for economic and political interaction, to decision-making structures that determine priorities among public problems and allocate resources to respond to them, to organizations that manage administrative systems and deliver goods and services to citizens, to human resources that staff government bureaucratic arenas. Getting good governance at times implies changes in political organization, the representation of interests, and processes for public debate and policy decision making. Not surprisingly, advocating good governance raises a host of questions about what needs to be done, when it needs to be done, and how it needs to be done. (Grindle, 2004:526)

Under these circumstances it has become demanding for most governments to make any reasonable progress in their governance. Grindle (2004) observes that there is little guidance on prioritization and sequence of execution. Although most African governments are taking the lead role in governance agendas through initiatives such as the New Partnership for Africa's Development (NEPAD), agendas are usually defined by the international development community and the list of reforms wanted is long and continues to grow over time. As shown in Table 1 below, the requirements related to governance reforms for a typical developing country have increased from 45 in 1997 to 116 in 2003. This clearly places an overwhelming burden on 
resource-starved countries. Grindle provides a plausible argument for re-defining good governance, pointing out that

there is no technical or easy fixes to what is inevitably a long, slow, reversible, and frustrating path toward better performing governments, but there may be ways of reducing the burden on those attempting to undertake the journey. (Grindle, 2004: 527)

Grindle (2004:527) has proposed a move from "good governance” to “good enough governance”, where the latter means a "condition of minimally acceptable government performance and civil society”. The focus should be on a few things that can be done to move economies forward in terms of eradicating poverty and improving people’s standard of living.

Table 1: The Good Governance Agenda (A count of governance items based on Items Referred to in World Development Reports)

\begin{tabular}{|c|c|c|c|c|c|c|c|}
\hline$x_{1}=$ & Examples of Governance Items & 1997 & 1998 & $\begin{array}{l}1999 / \\
00\end{array}$ & $\begin{array}{l}2000 / \\
01\end{array}$ & $\begin{array}{l}2001 / \\
02\end{array}$ & $\begin{array}{l}2002 / \\
03\end{array}$ \\
\hline $\begin{array}{l}\text { Characteristics of good } \\
\text { governance }\end{array}$ & $\begin{array}{l}\text { Checks and balances in government, } \\
\text { decentralization, efficient/equitable/independent } \\
\text { judiciary, free press, sound regulatory system, etc }\end{array}$ & 18 & 17 & 16 & 19 & 21 & 25 \\
\hline $\begin{array}{l}\text { Institutions for good } \\
\text { governance }\end{array}$ & $\begin{array}{l}\text { Bank and finance regulation, civil service, market } \\
\text { efficiency, managing decentralization, participation, } \\
\text { transparent budgeting, etc. }\end{array}$ & 8 & 11 & 10 & 17 & 21 & 21 \\
\hline Specific laws & $\begin{array}{l}\text { Trademark protection, enforcement of contracts, } \\
\text { biodiversity, foreign investment, labour standards, } \\
\text { intellectual property rights, etc. }\end{array}$ & 4 & 14 & 6 & 9 & 16 & 9 \\
\hline Specific policies & $\begin{array}{l}\text { Land reforms, land policy, capital markets, } \\
\text { community development, downsizing bureaucracy, } \\
\text { fisheries, insurance, social safety nets, etc. }\end{array}$ & 6 & 10 & 13 & 20 & 22 & 20 \\
\hline Specific services & $\begin{array}{l}\text { Services for: HIV/AIDS, communications, public } \\
\text { transportation, safe water, legal aid for the poor, } \\
\text { microcredit, targeted transfers, etc. }\end{array}$ & 7 & 17 & 12 & 22 & 11 & 20 \\
\hline $\begin{array}{l}\text { Broad strategies for } \\
\text { achieving specific goals }\end{array}$ & $\begin{array}{l}\text { Strategies for: asset creation for the poor, capacity } \\
\text { building in the public sector, empowering the poor, } \\
\text { engaging the poor, environment protection, } \\
\text { knowledge development, private sector } \\
\text { development, etc. }\end{array}$ & 2 & 9 & 9 & 19 & 9 & 21 \\
\hline Total & & 45 & 78 & 66 & 106 & 100 & 116 \\
\hline
\end{tabular}

\section{III: Issues and Challenges Facing SSA Governance Agendas}

There are many challenges facing developing countries in implementing "good governance” initiatives. It is not possible to discuss exhaustively all these challenges. I will focus on the following challenges that I consider to be the most important challenges confronting governance agendas today in SSA. These challenges are (1) reducing poverty levels, (2) implementing constitutional reforms and institutionalizing the rule of law, and (3) arresting the spread of HIV/AIDS pandemic. 


\section{III.1: Increasing Poverty Levels and Good Governance}

Perhaps one of the most important challenges facing governance agenda in most developing countries is poverty. Poverty is a major obstacle to effective public governance (Yusuf and Stiglitz [2000] and Rodrik [1998]). The widening gap between the poor and the rich has been the main cause of some of the civil wars and/or domestic conflicts that are common in most developing countries, especially in the SSA region. And yet poverty levels have continued to increase steadily over the years. UNCTAD (2002) reports that the people living below US\$1 per day in the SSA region has increased by approximately 46\%, that is, from 217 million in 1997 to 291 million in 1998. The report further explains that

the proportion of the population living on less than US\$1 a day in the least developed countries of Africa has increased continuously since 1965-1969, rising from an average of 55.8 per cent in those years to 64.9 per cent in 1995-1999. (UNCTAD, 2002:2)

Increased inequality undermines public governance in two ways. First, the poor are placed in a position where they cannot make any positive contribution to the economic development of these nations. A major ingredient to effective public governance is having the mechanism of voice to be heard and make contribution to the decision making process (Rodrik, 1998). And secondly, it creates an unstable environment conducive to civil strife and domestic conflicts. It is for this reason that good governance is widely viewed as an essential ingredient for alleviating poverty. But the key problem is having a governance agenda as a condition for reducing widespread poverty. This has been and continues to be a daunting task for most developing countries and in particular for those tackling poverty as a condition for debt relief. Table 2 below provides a World Bank summary of the dimension of poverty and governance - a guideline prepared to assist countries identify governance issues that must tackled in order to reduce poverty. Grindle (2004) explains why this approach will not work, arguing that governance agendas should not be used a mechanism for reducing poverty:

[A]mong them are the poorest countries in the world. Almost by definition their institutions are weak, vulnerable, and very imperfect; their decision-making spaces are constricted by the presence of international actors with multiple priorities, their public organizations are bereft of resources and are usually badly managed; those who work for government are generally poorly trained and motivated. Frequently, the legitimacy of poor country governments is questionable; their leadership may be venal and their commitments to change undermined by political discord; their civil societies may be disenfranchised, deeply divided, and ill equipped to participate effectively in politics. In 
such contexts, getting good governance as a route towards poverty reduction can overwhelm the commitment of even the most energetic reformers. (Grindle, 2004:526)

Nyong'o (2001) argues that the priority for such countries should be on poverty reduction in order to empower the poor to make a positive contribution to the governance agenda. Nyong'o points out that

the challenge for good governance in Africa needs to begin by recognizing and accepting that the legitimacy of any government of a modern democratic republic must begin with taking into account the basic needs of its citizens in terms of food, shelter, clothing, education, health, security and social solidarity or human dignity.

(Nyong'o, 2001:2)

Table 2: Dimensions of Poverty and Good Governance

\begin{tabular}{|c|c|}
\hline Poverty & Governance Issues \\
\hline Empowering the poor & \begin{tabular}{ll}
\multicolumn{2}{l}{ Rules for seeking and holding public office } \\
$-\quad$ Fair, transparent national electoral processes \\
$-\quad$ Power-sharing arrangements to ensure stability in heterogeneous societies \\
Oversight by political societies \\
$-\quad$ Parliamentary oversight with independent audit institutions \\
$-\quad$ Budget that is credible signal of government policy intentions \\
$-\quad$ Pro-poor policies \\
$-\quad$ Sound institutions for local and national representation
\end{tabular} \\
\hline $\begin{array}{l}\text { Improving coverage, } \\
\text { efficiency, and sustainability of } \\
\text { basic services }\end{array}$ & 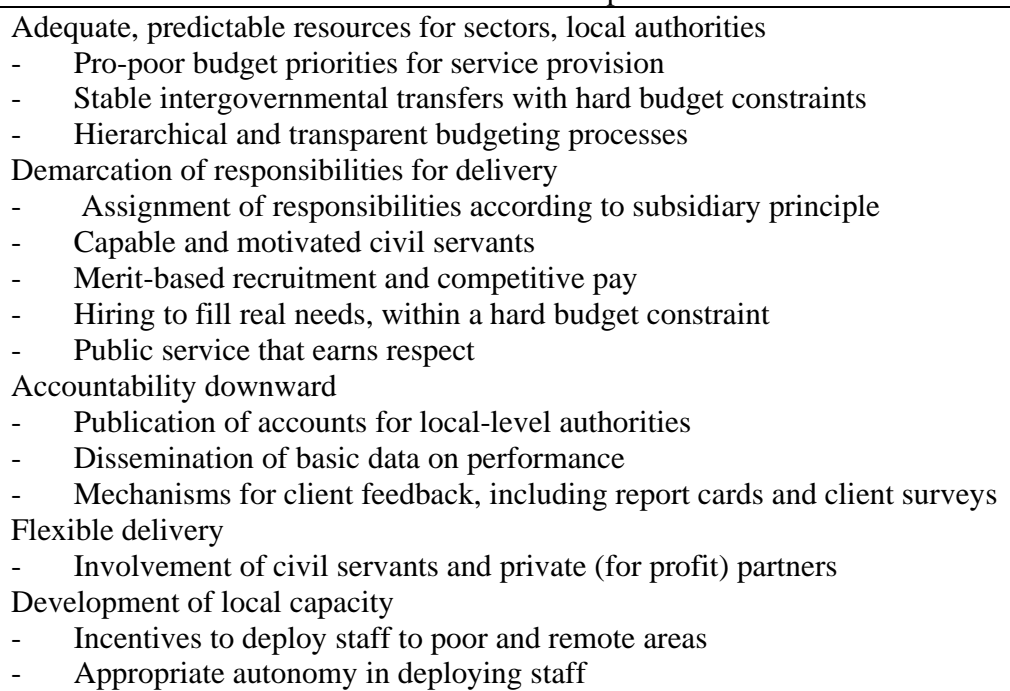 \\
\hline Increasing access to markets & $\begin{array}{l}\text { Legal and regulatory framework } \\
-\quad \text { Enforcement of antidiscrimination legislation } \\
-\quad \text { Incentives for deepening of credit and land markets } \\
\text { Methods for reducing exclusion } \\
-\quad \text { Enforcement of legislation against barriers to entry } \\
-\quad \text { Provision of information on labor and credit markets } \\
\text { Demarcation of responsibilities and budgeting } \\
-\quad \text { Procedures to support development and maintenance of infrastructure (e.g. } \\
\quad \text { rural roads) to enable physical access to markets }\end{array}$ \\
\hline $\begin{array}{l}\text { Providing security from } \\
\text { economic shocks, corruption, } \\
\text { crime, and violence }\end{array}$ & \begin{tabular}{ll}
\multicolumn{2}{l}{ Rules for sound economic management } \\
- & Hard budget constraint for subnational and aggregate fiscal discipline \\
- & Efficient administration of tax and customs \\
- & Independent central bank to carry out monetary policy \\
- & Safeguards against economic vulnerability
\end{tabular} \\
\hline
\end{tabular}




\begin{tabular}{|l|ll|}
\hline Poverty & Governance Issues \\
\hline & - & Recognition of property rights over physical assets \\
- & Access to speedy social insurance and other services through hub-and-spoke \\
& - & arrangements \\
- & Enforcement mechanisms \\
- & Independent and adequately funded court system \\
- & Access to speedy recourse and redress \\
- & Reliable and competent police \\
\hline & - & Efficient courts with competent judiciary and legal personnel \\
\hline
\end{tabular}

Source: Holmes, et al / World Bank (2001)

This approach of having good governance as an ingredient to poverty reduction is problematic. First, the consolidation of good governance can take a great deal of time (Grindle, 2004). Furthermore, Naim (1999) argues that these reforms are more complex because they require the involvement of a larger number of government agencies and social actors, and therefore the informational and coordination demands are more intense. For this reason, governance related conditionalities take a "long and, at times, painful historical processes and many that are now regarded as prerequisites of successful economic development were outcomes, rather than the causes, of economic development in today's advanced countries” (UNCTAD, 2002:52). Grindle (2004) has also pointed out that historically, many factors currently being considered preconditions for development were actually consequences of it. HaJoon Chang (2001) as cited in Grindle (2004) demonstrated that considerable economic development in developed countries occurred long before these countries had fully institutionalized democracies, modern financial institutions, and extensive social welfare services. Also Rodrick (1998) has argued that growth is often unleashed by relatively few policy changes and that institutional innovations can be introduced in the wake of reform, rather than serving as a precondition to it.

While governance reforms in most of these countries are highly desirable, they should be pursued independent of poverty reduction initiatives. It is important to assess which reforms are encouraged and pursued because they are good for governance, and which are particularly relevant to poverty reduction. But as rightly pointed out by Grindle (2004) many of the reforms advocated by IFIs as objectives for improving performance of governments are only conditionally connected to poverty reduction. Grindle (2004) further argues that

the danger is that governments will expend precious capacity, resources, and political capital making changes that may not have much impact on poverty, however laudable the changes are overall. There may be shorter term and more direct ways of increasing 
accountability and responsiveness to the poor while longer-term institutional changes for general governance improvement are discussed, debated, and initiated. (Grindle, 2004:535)

Based on the above discussion, poverty reduction initiatives should take precedence over the inherently slow and long term governance reforms.

\section{III.2: Constitutional Reforms and Institutionalizing the Rule of Law}

Most of the governance reforms being implemented in developing countries require major constitutional changes. For instance, the governance agenda issues confronting Tanzania include the need for a legitimate constitution; the creation of an effective legislature and a fair election system; the protection of human rights and the basic freedoms; and the creation of a system that allows for accountability, transparency, and integrity in the management of public resources and the participation of citizens in political, economic and social decision making (Mhina, 2002). At the core of all these issues is formulating an acceptable constitution to all parties. The process of making these constitutional changes acceptable to all parties is not an easy task for most countries. The process of constitutional reforms has proved to be not only time and resource consuming but also a delicate process that threatens the existing political stability in the country. Sikota Wina of The Post newspaper in Zambia, argues that constitutional problems are the biggest barrier to development in Africa. Wina observes that

Recent developments in Uganda, Tanzania, Ethiopia, Liberia and Kenya, for example, all provide cases where attempts at constitution changes have been bedevilled with corruption, repression, tear gas and shootings resulting in loss of life.

(The Post, November 23, 2005)

In Kenya, for instance, the country is at crossroads because various factions can not agree on the nature of constitution reforms. The constitutional review process has dragged for over 15 years and it is the most significant transition conflict in Kenya today. The process has created great uncertainty that threatens the existing political stability. The key challenge to good governance is to determine how to create the political will necessary to form a "new conjecture focused on bringing progress to all citizens” (Mhina, 2002:431). Mhina goes on to explain that

the crucial challenge to good governance in constitutionalism and rule of law is the maintenance of the political stability ... the stability has been built on the base of agreement on the rules of the political game. (Mhina, 2002:431) 
Political stability is critical for any constitution making process. What complicates the constitutional reforms process is the dominating role of the political elites. In most countries in Sub-Saharan Africa, the ruling elites are unwilling to let go of the status quo that protects their interests and allow extensive and acceptable constitutional reforms. The experience from most countries indicates that the ruling elites exclude other parties or stakeholders, especially those from the contending elite. It is for this reason that even in countries where the constitutional reforms have taken place, the resulting changes have gone against the spirit of those seeking constitutional reforms. For instance, Mhina (2002) points out those constitutional changes in Tanzania that called for reduction of presidential powers ended up increasing the powers of the president. By not involving all parties in the constitution making process, governments significantly reduce the possibilities of having a political legitimacy necessary to ensure that the legal and bureaucratic systems function effectively, efficiently and relatively honestly (Nyong'o, 2001). Mhina (2002:432) further explains that

the danger of the lack of involvement of many parties in the drafting and passing of measures for constitution reform is that the document passed will lack legitimacy and thus will not be perceived as binding by all citizens. After all, a constitution is a social contract, and one party cannot draw a one-sided contract with only its own signature and expect other groups and citizens to accept it. (Mhina, 2002: 432)

Making constitutional reform that is acceptable to all parties is a challenge that must be overcome by developing countries as they strive to implement their governance agendas. All inclusive constitutional reforms are necessary to ensure government legitimacy that is good for business, job creation, income generation and hence the fight against poverty.

Related to the problems of making constitutional reforms in SSA, is the challenge of institutionalizing the rule of law. This means that a legitimate and democratic government must be based on the rule of law. The key word is "legitimacy" which refers to "acceptance of a governing regime as correct, appropriate and/or right” (Brinkerhoff, 2005:5). Nyong'o further explains what it means to institutionalize the rule of law

[O]n the basis of rule and regulations laid down by the legislature, implemented by the executive arm of government and adjudicated by the judiciary (in the event of a dispute), individuals will seek to maximize their interests as citizens endowed with rights and obligations by the state. (Nyong'o, 2001:13) 
Institutionalizing the rule of law requires that every citizen will accept the principles and ideals of citizenship as a basis of exercising his or her rights and claiming the same from the state. This forms the basis of good governance. Institutionalizing the rule of law in SSA faces two formidable challenges. First, most citizens in SSA countries have what Peter Ekeh termed as the "two publics". The "first public" is where individuals have much closer ties to their family and clan than the state. This has been attributed to the colonialization process whereby the state regarded individuals as "subjects" and not as "citizens" and as result the individuals relate to the government in an alienated fashion. The "second public" relates to how the individual deals with the state - usually with little regard given to the obligation to obey the law. This "politics of two publics” thrives in SSA and poses challenges to good governance because individuals have not institutionalized the rule of law. Nyong'o explains:

[A]n individual regards it as ethically correct to misappropriate government funds as long as this goes a long way to satisfy family and kinship demands. It is this "politics of two publics" which has buttressed corruption -hence growing underdevelopment and poverty - in spite of the existence of the plethora of laws and regulations against corruption and misuse of public resources. (Nyong’o, 2001:14)

The problem of not observing laid down rules and regulations in most countries in SSA has persisted since the dawn of independence. Many of the problems related to poor governance relates to the lack of institutionalizing the rule of law. Sikota Wina of The Post daily newspaper in Zambia explains that

over 50 countries in Africa and since the dawn of independence a few decades ago changes of government in most of these countries have come about as a result of failure to observe any laid down rules regarding the transfer of power. (The Post, 2005)

The other problem with institutionalizing the rule of law relates to "engaging the citizens and enhancing their citizenship rights” (Nyong’o, 2001:14). Nyong'o argues that most people in SSA do not recognize the significance of their citizenship. This has worsened in the last two decades as most states have diminished their capability to provide essential services. Possibly this is the main reason why many people in SSA have no propensity to meet public obligations such as paying taxes. It is important that government create necessary incentives for people in order to "re-engage" them in the process of nation building. African governments must strive to guarantee “citizenship rights” that must include the "rights to basic standards of living” which includes health, education, shelter, social security, security and human rights (Nyong’o, 2001). 
Institutionalizing the rule of law is vital for good governance and it is a challenge that must be overcome in order to make progress in governance agendas.

\section{III.3: Arresting the Spread of the HIV/AIDS Pandemic}

The HIV/AIDS pandemic is now the biggest challenge facing most of the developing countries today. ${ }^{1}$ The pandemic continues to increase at an alarming rate. The number of people infected in 2003 was estimated to be 5 million while total number people living with HIV continues to increase from 35 million in 2001 to 38 million in 2003 (UNAIDS ${ }^{2}$, 2004). Of the 38 million adults and children estimated to be living globally with HIV/AIDS at the end of 2003, over 90\% were located within the so-called "Third" world and more than 25 million or $66 \%$ come from sub-Saharan Africa (UNAIDS, 2004). UNAIDS estimates that over 20 million have died since the first case was identified in 1981. The UN has described this pandemic as an "emergence that threatens development, social cohesion, political stability, food security and life expectancy and imposes a devastating economic burden on the continent and the dramatic situation needs urgent and exceptional national, regional and international action” (World Bank HIV/AIDS). In the words of former UN Secretary General, Kofi Annan, AIDS is “a new type of global emergency an unprecedented threat to human development requiring sustained action and commitment over the long term” (UNAIDS, 2004).

The HIV/AIDS pandemic is a formidable challenge for the implementation of governance agendas in SSA. De Waal (2003) argues that "the HIV/AIDS pandemic has far reaching consequences for governance and development" and that "the pandemic has set in motion processes that will transform the governance and economies of affected countries” (De Waal, 2003:1). The HIV/AIDS pandemic is adversely affecting the building of good governance in SSA in several ways. First, the HIV/AIDS pandemic is destroying the capacity of the most of these countries to deliver effective and efficient public service. The pandemic has significantly reduced the life expectancy on attaining adulthood (LEA) from 40-50 years to an average of 25

\footnotetext{
${ }^{1}$ The Copenhagen Consensus Project, with the cooperation of The Economist, gathered eight of the world's leading economists in Copenhagen in May 2004 to discuss and prioritize solutions to 10 serious global challenges. The 8 economists focused on how best to spend $\$ 50$ billion over the next four years to address such problems as malnutrition and hunger, conflicts, communicable diseases, sanitation and water, and subsidies and trade barriers. The "dream team" of economists assigned the highest priority to measures to control and treat HIV/AIDs (Copenhagen, 2004).

${ }^{2}$ The Joint United Nations Programme on HIV/AIDS (UNAIDS) is meant to coordinate the activities of the seven of the international agencies involved in AIDS work - the World Health organization; the United Nations Development Program; The United Nations Children Fund; UNESCO; the World Bank, and the UN International Drug Control Program
} 
years. This means that the disease is killing the economically active age group leading to loss of talented and experienced human resources. De Waal explains the impact of truncated LEA:

[T]he running of a bureaucracy such as a ministry, a large firm or an army depends on staff who have not only professional skills but also many years of experience and extensive networks of personal contacts... There are demands for recruitment and training, and inefficiencies as posts are left unfilled, senior staff do the jobs of their absent subordinates, or inexperienced juniors are promoted rapidly. Staff absences increases due to illness, attending funerals and caring for the sick, while morale also suffers due to absenteeism and declining institutional effectiveness. (De Waal, 2003:1112)

Second, the HIV/AIDS pandemic is undermining the capacity of these countries to generate government revenue necessary to provide the basic services. The costs associated with the pandemic have continued to increase over the years. These costs include the higher costs of recruitment, training, sick pay; costs related to the provision of health care for the infected; and the reduced revenue due to reduction in taxable economic activity (Moran, 2004:10). Moran (2004) points out that Botswana’s HIV/AIDS related costs are approximately 7 per cent of GDP and is expected to increase to 17 per cent of GDP in 10 years. Moran further argues that

demands of mounting programmes for HIV prevention and AIDS treatment, alongside upgrading other public health provision.. at minimum \$10-20 billion per annum .. and even if the money is available, the capacity to spend may be unavailable because not only are nurses and doctors dying more rapidly that they can be replaced by newly-trained professionals, but Africa is also exporting large numbers of health workers to the developed countries. (Moran, 2004:17)

Finally and perhaps the most of important, the HIV/AIDS pandemic is directly undermining the state's monopoly on violence. The most adversely affected occupational categories by the pandemic are soldiers and policemen/women. The HIV prevalence rates among soldiers and policemen is estimated to be in excess of $40 \%$ and is already contributing to the crisis in international peacekeeping in Africa. For instance, the HIV/AIDS prevalence among the South Africa military is between 60-70 per cent; close to one third of Namibia's 15,000-strong National Defence Force is infected (De Waal, 2003).

The Globe and Mail (November 30, 2005) notes that peacekeeping in Africa is facing an uncertain future because of the ravaging HIV/AIDS pandemic. The paper reports that a quarter of South Africa’s National Defence Force (SANDF) - the best-equipped and best-trained military force on the continent - is infected with HIV/AIDS, and the disease is taking its toll. 
The paper goes on to point out that "seven out of 10 military deaths in South Africa are AIDS related. HIV/AIDS is the biggest killer of armed forces in most SSA countries and this is having huge implications for the region's security (Globe and Mail [2005]; De Waal [2003]). Clearly, the pandemic is diminishing the capability of SSA states to maintain peace and order.

De Waal (2003) argues that the HIV/AIDS pandemic is the root cause for anti-social behaviour common in most countries in SSA. De Waal elaborates:

[T]he pandemic is likely to increase criminal behaviour at all levels, in part because of the multiplying numbers of orphans, many of whom will lack adequate socialization and who may be unemployed. The state risks, losing its monopoly on violence. (De Waal 2003:16)

It seems the pandemic is reversing the gains that have been made in strengthening and improving governance over the last few decades. Moran articulates this point, arguing

HIV/AIDS impacts on the critical infrastructures that sustain the security, stability and viability of modern nation-states, it undermines the stability of already weakened states and adds to their vulnerability to extremists and terrorists. As economies and infrastructures falter, family and social networks fragment, mortality rises, and social and political unrest or conflict become more likely. At the same time, however, the effect of HIV/AIDS on militaries, especially in SSA, means that at the same time as rising security challenges are faced, the ability and capacity of militaries to cope is diminishing. (Moran, 2004:14)

The HIV/AIDS pandemic is posing a serious challenge that directly undermines the building and strengthening of good governance. The impact of the pandemic on human resources and institutional capacity is calling for African governments to re-strategize on their governance agendas. Governments in the SSA, through their initiatives such as NEPAD, should focus their energies on arresting the spread of the pandemic instead of wanting to do everything from market liberation to judicial reforms.

\section{Summary and Conclusion}

This paper sought to highlight some of the challenges and issues associated with the implementation of governance initiatives. Although the pursuit and implementation of good governance is imperative in all countries of SSA, there are formidable challenges that must be considered and overcome in order to successfully implement governance agendas. African governments with the assistance of the donor community may write ambitious plans for 
improving governance and strengthening the various institutions and yet fail to make any tangible benefits in terms of improving the standard of living of their citizens. Governments must strive to focus their efforts and resources on achieving what is achievable and important within a given a timeframe. They should set reasonable targets and focus on a few areas that are critical and specific to the existing conditions in a particular country. They should also seek to fight poverty and empower the poor to make a positive contribution to the economic development of their countries. Efforts and resources should also be targeted at raising awareness and the level of education so that people can understand and institutionalize the rule of law. Even more important, the spread of HIV/AIDS must be arrested and contained otherwise all efforts and resources put into good governance will be a waste. As argued by Grindle (2004), the ultimate challenge for SSA countries and the donor community at large is to "move from axiomatic claims about the importance of institutions to more systematic analyses of institutional quality and its implications for various aspects of well-being such as access of the poor to essential services (and their) degree of empowerment”. It is important that governments refocus their energies and resources in providing basic services to their citizens so as to build their credibility and relevance that is necessary to ensure successful implementation of their governance agendas. 


\section{BIBLIOGRAPHY}

African Development Bank (AfDB) (2004) Strategy Paper on Governance, $<$ http://www.AfDB.org/projects/pdf/governance.pdf

Ahrens, Joachim (2001) “Governance, Conditionality and Transformation in Post-Socialist Countries” in Herman Hoen, ed., Good Governance in Central and Eastern Europe (Cheltenham: Edward Elgar), 54-90

Brinkerhoff, Derick W. (2005) “Rebuilding Governance in Failed States and Post-Conflict Societies: Core Concepts and Cross-Cutting Themes”, Public Administration and Development, 25, 3-14

Burnside, C., \& Dollar, D., “Aid, Policies and Growth” The World Bank, Policy Research Department, Working Paper No. 1777

Ciborra, Claudio, \& Navarra, Diego D. (2005) “Good Governance, Development Theory, and Aid Policy: Risks and Challenges of E-Government in Jordan”, Information Technology for Development, 11:2, 141-159

De Waal, Alex (2003) “How will HIV/AIDS Transform African Governance”, African Affairs, $102,1-23$

Easterly, W.R. "How did highly indebted poor countries become highly indebted? Reviewing two decades of debt relief”, The World Bank, Development Research Group, Working Paper No. 2225

Ekeh, Peter, P., (1975) “Colonialism and the Two Publics in Africa: A Theoretical Statement” Comparative Studies in Society and History, 17:1, 91-112 
Grindle, Merilees, S. (2004) “Good Enough Governance: Poverty Reduction and Reform in Developing Countries”, Governance: An International Journal of Policy, Administration, and Institutions, 17:4, 525-548

Gupta, Sanjeev; Davoodi, Hamid; \& Alonso-Terme, Rosa (2002) “Does Corruption affect income inequality and poverty”, Economic of Governance, 3, 23-45

Holmes, M; Knack, S., Manning, N; Messick, R., \& Rinne, J., World Bank Poverty and Governance Guideline tool kit, http://wbln0018.worldbank.org/prem/ps/iaamarketplace.nsf/0/70a73481b45de695852568 9c0050284c?OpenDocument

IMF, (2002), The IMF’s Approach to Promoting Good Governance and Combating Corruption A Guide, December, <http:/www.imf.org/external/np/gov/guide/eng/index.htm

IMF, (2003), The IMF and Good Governance, April, $<$ http://www.imf.org/external/np/exr/facts/gov.htm

Jayasuriya, Kanishka \& Hewison, Kevin, “The Antipolitics of Good Governance: From Global Social Policy to a Global Populism” Critical Asian Studies, 36, 4, 2004, 571-590

Kaufmann, D et al (1999) Governance Matters (Washington, World Bank, Policy Research Working Paper <http://www.worldbank.org/wbi/governance/pdf/govmatrs.pdf>

Mhina, Amos, (2000) “Good Governance and Development in Tanzania: Some Ethical Issues”, Journal of Social Philosophy, 31:4, 429-438

Mitchinson, Robin (2003) “Devolution in Uganda: An Experiment in Local Service Delivery”, Public Administration and Development, 23, 241-248 
Moran, Dominique (2004) "HIV/AIDS, Governance and Development: The Public Administration Factor”, Public Administration and Development, 24, 7-18

Naim, Moises (1999) "Fads and Fashion in Economic Reforms: Washington Consensus or Washington Confusion?” Foreign Policy Magazine, October 26 - Working paper Prepared for the IMF Conference on Second Generation Reforms, Washington, D.C., 124

Nyong’o, Anyang, P. (2001) “Governance and Poverty Reduction in Africa”, Economic Research Papers No. 68, African Development Bank,

Onyach-Olaa, Martin (2003) “The Challenges of Implementing Decentralization: Recent Experiences in Uganda”, Public Administration and Development, 23, 105-113

Organisation for Economic Co-operation and Development (OECD), Public Governance and Management, http://www.oecd.org/topic/0,2686,en 26493740511111 37405,00.html

Osaghae, Eghosa, E., (2003) “Colonialism and Civil Society in Africa: The Perspective of Ekeh’s Two Publics”, Paper presented at the Symposium on Canonical Works and Continuing Innovation in African Arts ad Humanities, Accra, Ghana, 17-19 September 2003

Panday, Devendra R (2004) “Role of Donors, Political Leadership, and Civil Society in Governance: Some Experience and Insights from Nepal” Journal of Development Policy and Practice, 1:1, 42-47

Pillay, Soma (2004) "Corruption - the challenge to good governance: a South African perspective”, The International of Public Sector Management, 17:7, 586-605

Rodrik, Dani (1998) The New Global Economy and Developing Countries: Making Openness Work, Washington D.C.: ODC - Policy Essay Mo. 24 
Roy, K.C., \& Tisdell, C.A. (1998) “Good Governance in Sustainable Development: The Impact of Institutions”, 25, 6/7/8, 1310-1325

Santiso, Carlos (2002) "Governance Conditionality and the Reform of Multilateral Development Finance: The Role of the Group of Eight”, G8 Governance Number 7

School of Oriental and African Studies (1997) "Roundtable of Heads of Government of Commonwealth Africa on Democracy and Good Governance in Africa”, Journal of African Law, 41, 2, 250-252

Tedesco Laura (2004) "Democracy in Latin America: Issues of Governance in the Southern Cone”, Bulletin of Latin American Research, 23, 1, 30-42

The Globe and Mail (2005), South Africa's military battling AIDS by Stephanie Nole, November 30, 2005

The Post (2005) “Constitutional Problems: Biggest Barrier to Africa's Development” November 22, 2005, retrieved from http://allafrica.com/stories/200511230241.html

UNCTAD (2002) Economic Development in Africa: From Adjustment to Poverty Reduction: What is New? <http:www.UNCTAD.org/eg/docs/pogdsafricad2.en.pdf>

The UNAIDS, 2004 Report on the Global AIDS Epidemic

Velayutham, S., \& Perera, M.H.B. (2004) "The Influence of emotions and culture on accountability and governance”, Corporate Governance, 4:1, 52-64

Wolfensohn, James D., “A Partnership for Development and Peace”, A Key address delivered at the Woodrow Wilson International Center, March 6 2002. < 
http://web.worldbank.org/WBSITE/EXTERNAL/EXTABOUTUS/ORGANIZATION/E XTOFFICEPRESIDENT/EXTPASTPRESIDENTS/PRESIDENTEXTERNAL/0,,content MDK:20040024 menuPK:232083 pagePK:159837 piPK:159808 theSitePK:227585,00 .html>

World Bank, (2004), Public Sector Governance, <http://www1.worldbank.org/publicsector/index.cfm>

World Bank, (2004), Africa Regional Brief, <http://web.worldbank.org/WBSITE/EXTERNAL/COUNTRIES/AFRICAEXT

World Bank, World Development Report 2002: Building Institutions for Markets

World Bank, (2000), Reforming Public Institutions and Strengthening Governance: A World Bank Strategy (World Bank: Public Sector Group - Poverty Reduction and Economic Management (PREM) November 2000

World Bank, The World Bank Annual Report 1997

World Bank, (1989), Sub-Saharan Africa: From Crisis to Sustainable Development, Washington, World Bank

World Bank (1988) Adjustment Lending: An Evaluation of Ten Years of Experience, World Bank: Washington D.C.

World Bank HIV/AIDS, http://www1.worldbank.org/hiv_aids

Yusuf S. and Stiglitz (2000), “Development Issues: Settled and Open,” Gerald M. Meier and Joseph E. Stiglitz, eds. Frontiers of Development Economics, New York: The World Bank and Oxford University Press. 227-269 